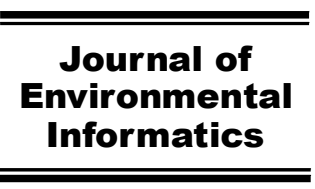

www.iseis.org/jei

\title{
Framework for Sustainable Low-Income Housing Projects Using Building Information Modeling
}

\author{
M. Marzouk ${ }^{1, *}$, S. Azab ${ }^{2}$, and M. Metawie ${ }^{3}$ \\ ${ }^{1}$ Structural Engineering Department, Faculty of Engineering, Cairo University, Giza 12613, Egypt \\ ${ }^{2}$ National Authority for Remote Sensing and Space Sciences (NARSS), Cairo 19765, Egypt \\ ${ }^{3}$ Structural Engineering Department, Faculty of Engineering, Cairo University, Giza 12613, Egypt
}

Received 2 December 2014; revised 18 February 2015; accepted 1 May 2015; published online 24 August 2016

\begin{abstract}
Governments in developing countries serve low income people by constructing low income housing projects. Most of total life cycle cost (LCC) of these projects is incurred during the operational phase, making these projects lose their economic aspect of sustainability. Decreasing the cost of low income housing projects and taking into consideration the available resources are two crucial facets that should be taken into consideration. Therefore, this paper focuses on two aspects of the sustainability of building through its life cycle, which are environmental and economic aspects using environmentally friendly materials in construction. To accomplish this aim, a framework is developed that integrates Building Information Modeling (BIM) with computer simulation, optimization and system dynamics in Low Income Housing (LIH) projects. The developed framework helps in determining LIH project duration and selecting the optimum alternative with to material systems. The sustainability aspects of building are achieved by considering a LCC of these buildings and the number of points that can be awarded under the Leadership in Energy and Environmental Design (LEED) rating system. It aids government and/or contractors in adopting BIM technology to minimize life cycle cost while achieving maximum LEED materials credits points for LIH projects. Social Housing project in Badr City-Egypt is considered as a case study to demonstrate the use of the developed prototype and to illustrate its essential features. The results have shown that selection of sustainablebuilding materials for the construction has a crucial role in the formation of a sustainable building as they affect the performance of building. Therefore, the Egyptian government should consider building materials with sustainable properties and a low LCC in the design phase to mitigate the negative impacts of LIH projects.
\end{abstract}

Keywords: Building Information Modeling, computer simulation, optimization, system dynamics, Low Income Housing

\section{Introduction}

Housing has a fundamental relevance indispensable for any community due to its effects on quality of life and human welfare. Ambition of many Egyptians lies in owning a house. The continuing rise in housing costs currently in Egypt has adverse social effects on low-income households. In Egypt, these households represent about $80 \%$ of the total population. Therefore, their basic needs that represent in housing cannot be fulfilled by the open-market policy (JLL, 2011). For reducing the gap between the demand and the supply of the housing units for low-income households, Egyptian government has adopted many affordable housing strategies from 1950s up till now to meet the growing needs for housing demands. However, all these strategies do not take into their consideration any sustainable practices and/or green materials in cons-

\footnotetext{
* Corresponding author. Tel: +202 35678492; fax: +202 35723486.

E-mail address: mm_marzouk@yahoo.com (M. Marzouk).
}

ISSN: $1726-2135$ print/1684-8799 online

(C) 2016 ISEIS All rights reserved. doi: 10.3808/jei.201600332 truction (Mansour et al., 2007). Consequently, traditional construction approach of such housing has contributed to raising costs of low-income housing (LIH) over its life cycle, where most of these costs are incurred after construction during the operating phase for being unhealthy, besides its undesirable impacts on the environmental performance not only nationally but also globally. On a global scale, about $25 \%$ of all ozonedepleting chlorofluorocarbons are emitted by building air conditioners and manufacturing building materials (Bilec, 2007). Almost $50 \%$ of energy flows are used for weather conditioning in heating and cooling the buildings (Pulselli et al., 2007). For that, there is a need to integration the sustainable practices in earlier stages of building during planning and design processes. Selection of environmentally friendly building materials has been considered as the easiest method for designers to incurporate principles of sustainability in building projects (John et al., 2005). From this point, the Egyptian government can construct a large number of housing units with less possible use of the country's energy resources if principals of sustainability and low cost materials are employed (Mansour et al., 2007). However, there is a growing concern for many stakeholders about creating sustainable buildings with the belief 
that green building costs outweigh the traditional building costs. This misconception is due to the lack of perception of the concept of cost and focusing on initial costs without considering a life cycle cost (LCC) of a sustainable building that leads to the continuation of minimizing the initial costs of project rather than minimizing the total project cost. This paper aims to determine a LIH project duration and selecting the optimum material alternative systems taking in consideration two aspects of sustainability of building; environmental and economic aspects. The sustainability aspects of building are achieved by considering a LCC of these buildings and the number of points that can be awarded under the Leadership in Energy and Environmental Design (LEED) rating system.

The LEED (Leadership in Energy and Environmental Design) has been developed by the U.S. Green Building Council in 2000 to quantify the degree of the environmental sustainability of building designs through providing a framework from recognized measurements for developing and operating high-performance green buildings. Where, LEED is considered as a point-based rating system, which means that the performance of building projects is evaluated according to the number of points that can be awarded for each credit when it satisfies green building criteria (USGBC, 2012). The Performance of building is evaluated across five key areas of environmental and human health: sustainable site development, water savings, energy efficiency, materials selection, and indoor environmental quality. There are also two additional areas: innovation in design and regional priority. Innovation in design area deals with sustainable building expertise and design measures that did not discuss by other areas. While, regional priority gives bonus points based on geographical locations of projects. However, projects outside the US are not eligible for regional priority credits (USGBC, 2009). Azhar et al. (2011) proposed a conceptual framework shows that sustainable BIM softwares may be used for preparing LEED credits supporting documents directly or indirectly. Despite the importance of achieving the criteria of all LEED's areas for the performance of building, a materials selection area represents the highest priority for developing a sustainable building (Florez and Castro-Lacouture, 2013).

\section{Literature Review}

Plenty of efforts have been spent to model construction operation using computer simulation. Marzouk and Moselhi (2004) presented a framework that utilize computer simulation and genetic algorithms for optimizing earthmoving operations. The main objectives of the optimization were to minimize time and cost of earthmoving operations, taking in consideration equipment availability, project indirect cost, and a group of qualitative and quantitative variables that influence the productivity of earthmoving operations. Zhang (2008) presented a framework that integrates simulation with multi-objective optimization for earthmoving operations. It utilizes par-ticle swarm optimization to select best equipment-configurations through earthmoving operations simulation. Marzouk et al. (2008) presented a special-purpose simulation mo- del that aids government agencies in planning the construction of bridges' decks using cast-in-place and precast balanced cantilever techniques. Marzouk et al. (2010) presented a framework that utilize genetic algorithm to determine the duration and total cost of the pre-cast hollow core with hollow blocks bearing walls method for low income projects. Song \& Eldin (2012) integrates real-time tracking with heavy construction operations simulation for automatic schedule updating during construction field operations. Cheung et al. (2012) proposed a multi-level cost estimation based tool for early buildings designs by the integration of BIM model environment with a proposed cost estimation module. Chen and Huang (2013) proposed a 3D visualized modeling method for Discrete-event simulation of transport operations in construction. This method integrates Augmented Reality technology with STROBOSCOPE as a simulation engine for modeling transport operations in construction. Based on this review, it can be concluded that the integration of the multi-criteria decision approaches in a framework has a great ability in improving the decision-making process in the selection methodology. Therefore, this paper proposes a framework that integrates Building Information Modeling (BIM) with computer simulation, optimization and system dynamics to develop sustainable LIH buildings to determine low-income housing project duration and select the optimum material alternative systems taking in consideration sustainability aspects.

\section{Life Cycle Cost Analysis}

Creating a sustainable building for low-income groups requires selecting building materials consumes a minimum costs through the life cycle of the building. LCC analysis is as an engineering economic analysis tool that uses to evaluate the total cost of asset ownership (Stanford University, 2005; Fuller, 2010). It allows the designer or manager to quantify the differential costs of various competing alternatives of building materials over its expected life cycle within the limits of the available data. Therefore, it does not guarantee a particular result, but allows making a reasonable comparison among the alternatives and then it can determine the most cost-effective option among them (Frenning et al., 2001). LCC of the project can be evaluated by considering all relevant economic factors associated with each alternative of materials for the construction operations, starting from initial cost to end of life cost including discounting rates of money. In this paper, the components of a life cycle cost analysis are divided into four economic groups: initial cost (construction cost), operational and maintenance costs, replacement cost, and end-of-life costs including residual value. These costs are individually estimated for each competing alternative in each construction operation of building. Life cycle cost of building is the sum of LCC for all systems of building. As any residential building, it often has a life span of 50 to 100 years. For that, some cost elements will be incurred at the outset and others may be incurred at different times throughout its lifespan. It is therefore practicable, these costs can not directly comparable for getting LCC of a building. In order to accurately assess the LCC, 
the time value of money must be incorporated into estimations using discounting process that converts future costs to present value. This process is conducted by employing a discount rate, which reflects the opportunity cost of money over the time horizon (Fuller, 2010).

Net Present Value method (NPV) is the most commonly used economic evaluation method for LCC. It is based on time value of money concept to convert all future cash flows to their present-day equivalent value (Kibert et al., 2010). For that, NPV method is used to evaluate the economic performance of competitive alternatives in this research. For obtaining an accurate comparison between different alternatives by using NPV method, the analysis period and the discount rate must be the same for all alternatives. For that, the length of study period is considered the normal lifespan of a LIH building in Egypt (i.e. 50 years) and the discount rate taken for this research is 5\%. According to Beatty (2002), LCC analysis of a building is performed by following four steps: (1) identifying the life-cycle period and costs for each alternative, (2) defining all the pertinent costs of ownership for each alternative, (3) estimating the total LCC for each implementation option so that it would be able to be directly compared to other options, and (4) analyzing and interpreting the results. Equation (1) is used to calculate NPV for each building system.

$N P V=I+R+A+N-S$

where I is present value of initial costs; $R$ is present-value of replacement costs of building systems and/or components; A is present value of annual recurring program, operation, maintenance, utility and other costs; $\mathrm{N}$ is present value of nonannual recurring program, operation, maintenance, utility, and other costs, and $\mathrm{S}$ is present-value of residual value (resale value, scrap value, salvage value) less disposal and demo lition costs. To achieve the desired aim of this research, this paper presents a framework that integrates Building Information Modeling (BIM) with optimization, System Dynamics (SD), and Simulation in Low Income Housing projects in an effort to assure sustainability. Equation (2) is used to determine the present value $\mathrm{P}$ for construction cost, replacement cost, and salvage value or resale value that occur after $n$ periods in the future.

$P=F(1+i)^{-n}$

Construction cost consists of material cost, labor cost and equipment cost. And it occurs at time zero. Replacement cost depends on the system service life. It occurs at the beginning of the system service life. If the system has a service life less than 50 year, it will be replaced more than one time. Salvage value is like replacement cost, but it happens at the end of system service life.

Operational costs contain the non-investment costs related to the use of building system including energy costs. While, maintenance costs are the expenses of amendment, refinishing, or replacing sub components such as gaskets including the cost of regularly scheduled preventative maintenance and emergency repairs. Equation (3) is used to determine the present worth $\mathrm{p}$ for the annual operational and maintenance cost A.

$P=A\left[\frac{(1+i)^{n}-1}{i(1+i)^{n}}\right]$

where $\mathrm{i}$ is the interest rate used, and $\mathrm{n}$ is the operational life time (i.e. 50 years).

\section{Proposed Framework}

The developed framework (named LIH_Sustain) helps government agencies and/or contractors in integrating BIM technology with optimization and system dynamics in minimizing life cycle cost while achieving maximum LEED materials credit points for $\mathrm{LIH}$ projects. Integrating BIM with computer simulation assists in determining total duration for a LIH project, taking in the consideration the number of resources used and number of the building required to be built. While, system dynamics model is used as a decision making-tool for the possibility of establishing a sustainable housing for Low-Income groups using green-building materials. This is done by analyzing the scenario that will be chosen by the decision-makers from possible optimum solutions that were extracted from optimization model. SD can be used for monitoring the costs in the different years of operational lifetime of the building. The two main functions of the proposed framework are; determining low-income housing project duration and selecting the optimum material alternative systems taking in consideration sustainability aspects. The framework can develop the low-income housing projects with unlimited number of building units with any number of floors that ranges from one to six. The framework is also flexible with respect to the type of input data relating to activities duration. It has the ability to receive the productivity rate for each resource as a probability distribution or a discrete number. Then, it calculates the corresponding duration for activities in a dynamic manner. LIH_Sustain is implemented using .net C\# windows application language. It utilizes Stroboscope (Martinez, 1996) as simulation engine. The proposed framework consists of four main components; BIM model, Project Duration Simulation model, LEED optimization model, and System Dynamics model (see Figure 1).

The BIM model is developed using Autodesk Revit architecture (Building information modeling software). This model is used to represent the geometrical information and the other properties of LIH building such as building elements properties, material properties and its quantities, design alternatives and project location. The different material data are extracted from the generated model. These data are used in calculating project duration and materials cost. Also, the model allows LEED credit calculation by extracting these quantities from the BIM model and importing them in the optimi- 


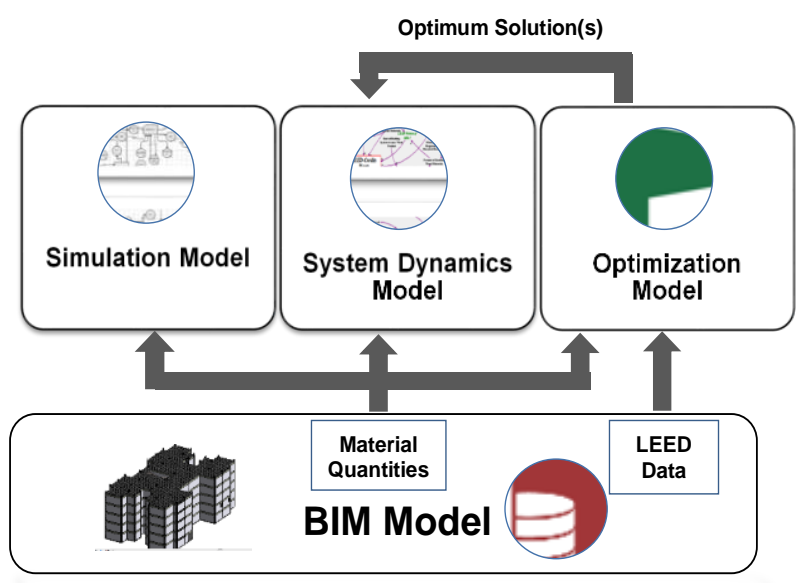

Figure 1. Proposed LIH_Sustain framework.

zation model. It also allows integrating the extracted data with the simulation model to calculate the project duration, taking in consideration utilized resources. Simulation model is developed using Stroboscope simulation engine (Martinez, 1996). It is responsible for estimating the total duration of low-income housing projects. LIH building is divided into four main processes; excavation, foundation, concrete skeleton, and finishing. Figure 2 shows a sample of the proposed model.

\subsection{Sustainable Material Optimization Model}

This Model focuses on the credits of materials selection area in LEED 2009 for new construction and major renovations. Five credits are selected to track the effect of their characteristics on the evaluation. These credits are Materials Reuse, Recycled Content, Regional Materials, Rapidly Renewable Materials, and Certified Wood. For each credit, individual points are awarded when selected materials achieving the requirements based on its sustainable data. The number of LEED points awarded for the targeted five credits are eight points. Additional points are provided for achieving exemplary performance that exceeds the level of requirements for each credit. One point is awarded for each exemplary performance achieved by passing double the credit requirements and/or passing the next incremental percentage threshold of each credit. A maximum of three innovation points in design can be awarded for the exemplary performance (USGBC, 2009).

LEED Materials calculator uses the predefined sustainable material data to calculate the LEED points achieved and its related life cycle cost (LCC). The cost is determined using the quantities extracted from Revit and the predefined alternatives. A typical Low Income Housing (LIH) building consists of eleven systems of building materials: PC foundation casting, RC foundation casting, Water Insulation, Columns Casting, Slabs \& beams Casting, Block Works, flooring, plastering, Painting, Roof insulation, and Windows \& Doors Installation. Each system has a number of possible materials alternatives. Each alternative is associated with a certain sustainable material data and cost. Table 1 illustrates an example for material alternatives of flooring system. For calculation of total LEED credits achieved for a specific alternatives scenario, LEED calculator has to calculate the following for this scena-

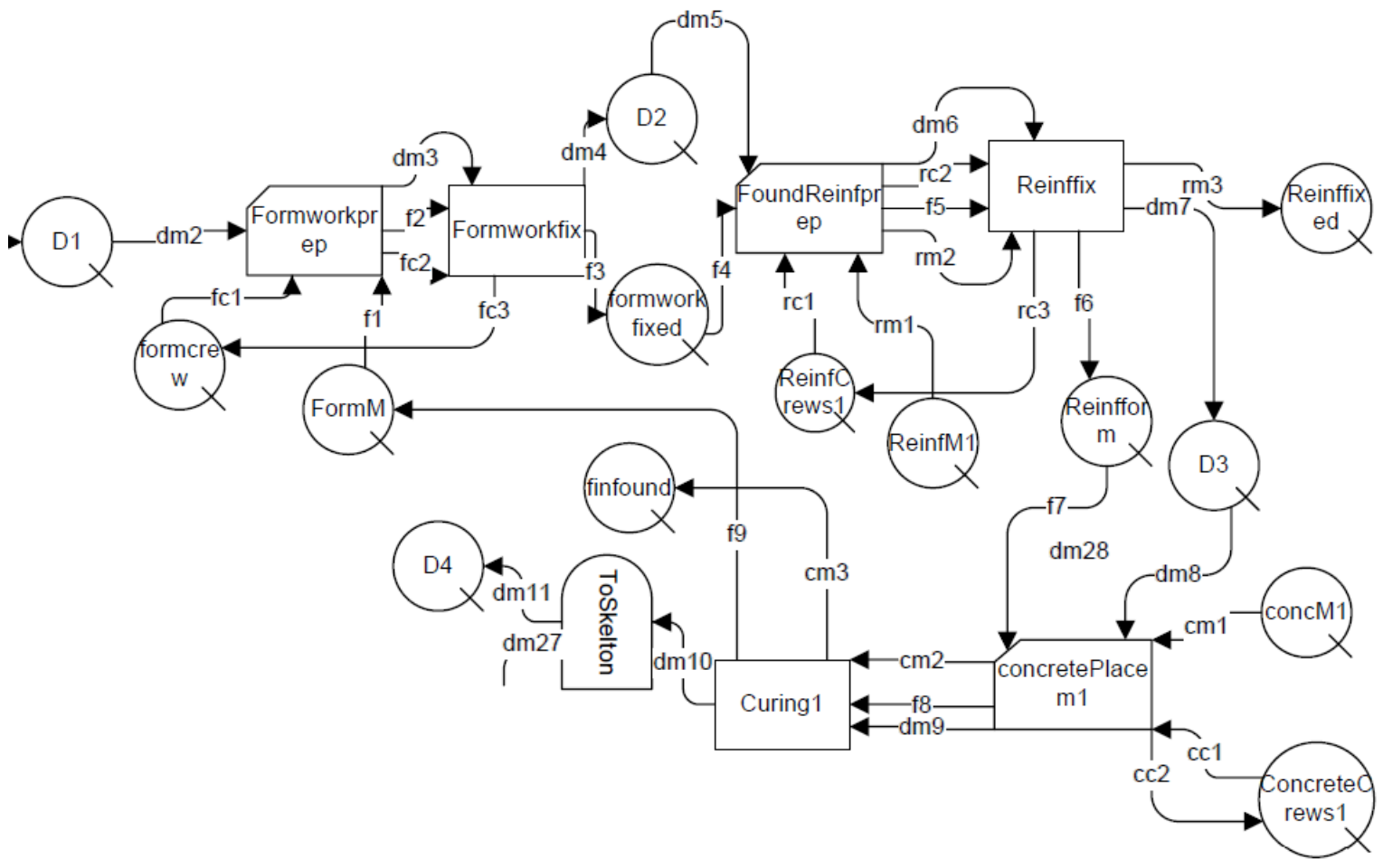

Figure 2. Sample of the proposed simulation model. 
rio:

1. Total material initial cost.

2. Total reused Materials Percentage using Equation (4).

3 . Total material recycled content value and percentage using Equations (5) and (6).

4. Total regional Materials Percentage using Equation (7).

5. Total rapidly renewable Materials Percentage using Equation (8).

6. Total Certified Wood Percentage using Equation (9).

Then it calculates the total achieved credits based on this scenario.

Percentage $\operatorname{Re} u$ sed $=\frac{\text { Total } \operatorname{Cos} t \text { of } \operatorname{Re} \text { used Material }}{\text { Total Materials } \operatorname{Cos} t} * 100$

Recycled Content Value

$=(\%$ Postconcumer R.C.* Materials $\operatorname{Cos} t)+$

0.5(\% Preconsumer R.C.* Materials $\operatorname{Cos} t)$

Percentage Recycled Content

$=\frac{\text { Total } \operatorname{Re} \text { cycled Content Value }}{\text { Total Materials } \operatorname{Cos} t} * 100$

Percentage Re ginal Material

$=\frac{\text { Total } \operatorname{Cos} \text { tof } \operatorname{Re} \text { gional Materials }}{\text { Total Materials } \operatorname{Cos} t} * 100$

Percentage Rapidly Renewable Material

$=\frac{\text { Total Cost of Rapidly Renewable Material }}{\text { Total Materials } \operatorname{Cos} t} * 100$

Percentage Certified Wood Material

$=\frac{\text { FSC }- \text { Certified Wood Material Value }}{\text { Total NewWood Material Cos } t} * 100$

In order to select the optimum building materials that minimize LCC cost while achieving maximum LEED credit, an optimization model is developed using Microsoft Excel add- in which uses NSGA-II genetic algorithm to solve multipleobjective problem. NSGA-II is multi-objective optimization algorithm based on non-dominated sorting. The procedure of NSGA-II optimization model developed by Deb et al. (2002) has six main steps:

- Step 1:

The optimization model retrieve the parameters needed by the NSGA-II algorithm, which include: number of generations (g), population size (s), mutation rate $(\mathrm{m})$, and crossover rate (c), and then the algorithm generate the first population with different (s) solutions.

- Step 2:

For each solution in the population, the two main objective functions (cost and LEED Credits) are calculated based on the LEED Calculator.

- Step 3:

In this step the algorithm finds all solutions that are not dominated by other solutions

- Step 4:

All solutions defined as non-dominated solutions in the previous step constitute The first front of non-domination, then the solutions of first front are excluded and step 3 are repeated to form the second non domination front, which dominated by the individuals in the first front only and so on.

- Step 5:

After completing the non-dominated sorting, each solution in each front is assigned rank values. First front solutions are given a fitness value of 1 and second front solutions are assigned fitness value of 2 and so on. In addition to fitness value another parameter (crowding distance) is calculated for each individual. The crowding distance parameter measures how close an individual is to its neighbors. Large average crowding distance will result in better diversity in the population.

- Step 6:

A new child population is created using genetic algorithm operators of selection, crossover and mutation. The selection operator chooses the solutions that will go through the reproduction process. Solutions with better (lower) rank will be selected. If there are two solutions have the same rank then the solution with larger crowding distance will be selected. In case that both solutions have the same rank and also crowding distance then selected solution is chosen randomly. The cro-

Table 1. Material Alternatives of Flooring Activity

\begin{tabular}{llll}
\hline \multirow{2}{*}{ Task Name } & \multicolumn{2}{c}{ Sustainable Material } & \multirow{2}{*}{ LCC Cost (LE/unit) } \\
\cline { 2 - 3 } & ID & Name & 54.1 \\
\hline Flooring & Fl1 & Ceramic Tile With Recycled Glass 75\% RC & 198.9 \\
& Fl2 & Linoleum Flooring & 83.9 \\
& Fl3 & Terrazzo & 858.6 \\
& Fl4 & Wood Plank Flooring & 767.3 \\
\hline
\end{tabular}


ssover operator is designed to share information between individuals to create entirely new solutions, which have some of the attributes of their parents. Normally, two solutions are crossed at randomly determined point and swapped the variables at this point. The mutation operator is designed to provide new genetic material during an optimization. Without the mutation operator, the algorithm could find locally optimal solutions without searching for better globally optimal solutions. The mutation operator works by selecting a gene at random in a chromosome and changing it to a random value.

Then, a new combined population with $2 \mathrm{~s}$ size is formed by combining the initialized population with the new child population. Then, the previous steps are carried out for the new population to assign the fitness and calculate the crowding distance for each solution in the new population to be sorted again based on non-domination and only the best (s) individuals are selected. The previous steps are continued till the number of generations is completed.

The decision variables (genes) for this algorithm are the main 11 system of building materials: Pc foundation casting, Rc foundation casting, Water Insulation, Col Casting, Slab \& beam Casting, Block Works, flooring, plastering, Painting, Roof insulation, and Windows \& Doors Installation.

\subsection{System Dynamics Model}

System dynamics (SD) is considered a simplified modeling technique used for the representation of the real-world behavior with time. It is typically used as a decision-making tool, especially for complex issues and systems. This is due to its ability in giving a broad vision on how various components interacts with each other over time by focusing on the feedback processes that take place within the system as well as concentrating on the key to the problem and its content (Tang and Vijay, 2001). In addition, SD provides systematical explanations and alternatives for policies that are often discerning and counterintuitive (Park et al., 2009). What-if scenarios can be created using SD technique for understanding how small changes can effect on a whole complex system (Saunders, 1998). Therefore, it facilitates quantitative computer simulation modeling and analysis to help understanding of system structure (Wolstenholme, 1985). Since developing SD in the 1950s by Professor Jay W. Forrester to assist corporate managers in improving their understanding of industrial processes (Radzicki and Taylor, 2008), several studies have utilized system dynamics technique for simulating the scenarios and analyzing the policies in many different applications in business, economic, agricultural, social, and environmental systems.

In construction field, most of construction projects management issues have been addressed in many of research contributions using system dynamics modeling as a simulation engine in studying the impacts of change and rework in construction project management systems (Love et al., 2002); investigating the cost and time overruns of construction project (Marco and Rafele, 2006); studying strategies of Design-Build delivery system (Park et al., 2009); assessing the effects of design errors in construction projects (Han et al., 2013); opti- mal selection of green building materials (Marzouk et al., 2013); analysis of environmental and economic effects of construction and demolition waste (Yuan et al., 2011; Marzouk and Azab, 2014); determining the waste disposal charging fee (Yuan and Wang, 2014); assessing the effects of recycling aggregate on sustainable road construction (Mallick et al., 2014); monitoring construction workers' safety attitudes and safe behaviors (Shin et al., 2014); study the impacts of green building related policies on the GHG emissions stock (Onat et al., 2014).

For better understanding the problem and clarifying the interactions amongst the various components of system for evaluating effects of selection the green building materials on LCC and LEED credits points that should be awarded for LIH building, it is needed to account the problematic behavior of the system. Casual-loop diagram (CLD) is presented in this paper using VENSIM software to visualize cause and affect relationships of the key variables within a system (see Figure 3). The first step towards developing the model structure (CLD) is defining the key variables forming the model boundary and affecting the model behavior. The key variables are dividing into three main groups. The first one contains the essential construction operations of LIH building, which are represented in the model by one variable named building system. The second group covers the essential variables that represent the basic requirements of the LEED credits. These requirements are based on the sustainable properties of building materials that are selected for building such as the percentage of reused material, post-consumer recycled content, pre-consumer recycled content, regional material, rapidly renewable material, and certified wood. The third group contains the four main groups of LCC of building (initial cost, operational and maintenance costs, replacement cost, and end-of-life costs including residual value).

In the proposed model, systems of building have two costs. The first one is sustainable cost, which is used for the calculations of LEED credits points, whereas the second one is the cost of their life cycle. The second step towards developing CLD is to consider how the interaction of different variables in each group with each other to decide the final environmental and economic behaviors of building. As depicted in Figure 3 , If any changing occurs in the state of any variable in model, it will affect directly on the behavior of building. As such, the economic behavior of building will be effected by changing the LCC value. For that, life-cycle cost of any construction operation in LIH building is increased due to increasing the quantity of materials necessary for these operations and the costs's unit from initial costs, operational and maintenance costs, replacement costs, and end of-life costs through their life cycle. As a result, LCC of building will be increased when more costs are incurred depending on the choice of a certain type of building materials. This in turn leads to creating negative effect on the economic behavior of LIH building.

Also, environmental behavior of building will be affected by changing the number of LEED credits points awarded for it. As per Figure 3, according to materials and resources credit 
3: Materials Reuse (MRc3) that encourages the use of reused materials, the percentage of reused materials is affected by the type of materials that used in each construction operation where if the selected materials for the construction operations have a significant percentage of reused materials; this leads to an increase in total costs of reused materials. As a result, percentage of reused materials will be increased when more reused materials takes place instead of virgin material. This in turn leads to an increase in the chance of earning this credit. By referring to impacts of materials and resources credit 4: Recycled Content (MRc4) on number of credits that will be gained for project, it can be noted also if the selected materials for the its construction operations contain a significant percentage of recycled materials whether post-consumer or pre-consumer recycled content this leads to raising the recycled content value for each building system and thereby the total recycled content value of project will be raised. As a result, total percentage of recycled content will be raised. This in turn leads to raising the chance of earning this credit. However, the post-consumer recycled content has a greater value than pre-consumer recycled content owing to its increased environmental benefits over the life cycle of the product (USGBC, 2009). Materials and resources credit 5: Regional Materials (MRc5) gives the priority for building materials and products that are extracted and manufactured within the region. For that, if the materials that are used in the project are considered regional materials, it will lead to an increase in total cost of regional materials and then raising percentage of these materials in the project based on cost, which leads to increasing the chance of improving environmental performance, which expressed by LEED points acquired. By referring to materials and resources credit 6: Rapidly Renewable Materials (MRc6) that encourages the use of rapidly renewable materials, it can be noted that if the selected materials contain a significant percentage of rapidly renewable materials, this will lead to raising their content in the project and then helps in raising the total cost of rapidly renewable materials, which leads to increasing the total percentage of rapidly renewable content materials for project. As a result, the number of LEED points for this credit will be gained. For materials and resources credit 7: Certified Wood (MRc7), raising the use of certified wood products and materials in project helps in earning the credit. This reflects the keenness of the project of using sustainable timber, preserving wildlife habitat and biodiversity, maintaining soil and water quality, minimizing the use of harmful chemicals, and conserving forests that have high value.

\section{Framework Implementation}

As referred to earlier, the framework contains four main software components (BIM Model, Simulation Model, Optimization Model, and System Dynamic Model). These components have been built or coded using different programming tools. A computer prototype, name LIH_Sustain, is developed

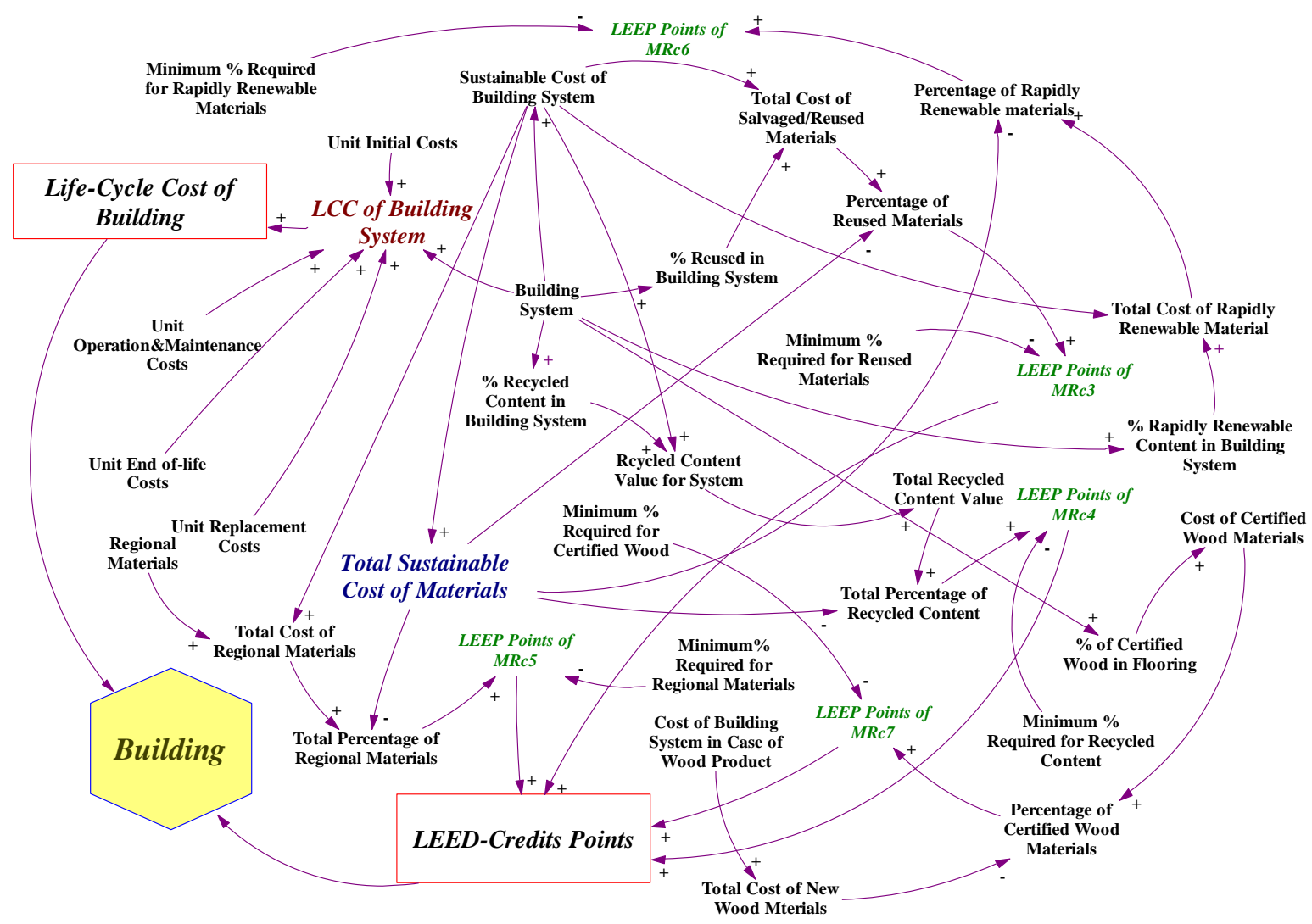

Figure 3. A causal loop diagram of assessing LCC of LIH building based on LEED-rating system. 
using .net C\# windows application to integrates all of these models. Approximately 2500 coding statements have been written to receive different data from the end user. The main function of the prototype is helping the user to input all data in an easy manner and then obtain the models outputs. Figure 4 depicts the data form Data for LIH Activities. BIM model is developed using Autodesk Revit software. The BIM model is extracted into a database file. This file contains more than 230 tables. The relationships between these tables are also exported. To retrieve the needed data for simulation model or sustainable model from the BIM model, five queries were designed. These queries are used to retrieve columns, beams, walls, floors, and foundations data. For example, column query is used to summarize the quantities for concrete, reinforcement and formwork for columns per each level. The quantities of these materials are used in calculating project duration through simulation. Also, they are used in calculation LCC and LEED Credit through optimization model.

Stroboscope engine is used to code simulation model for the LIH building, whereas, Visio 2007 is used to represent the activities and its relations as graphical network. It uses Stroboscope to ease the process of modeling and reduce code writing since it supports graphical format. The model is exported into a str file. The main data needed to run the simulation is the number of crews and the productivity for Combi activities in the model. Also, the quantities date retrieved from BIM model, no. of floors and no. of building are needed to run the model. Figure 5 shows sample of the code that allows opening the simulation file and writing in the opened file. On the other hand, STELLA software is used for supporting the analysis of quantifing numbers of LEED credits and LCC of LIH building. A link with building information modeling (BIM) program has been conducted for populating the SD building model with the data necessary to represent LIH building.

\section{Case Study}

This section describes the implementation of the propo-

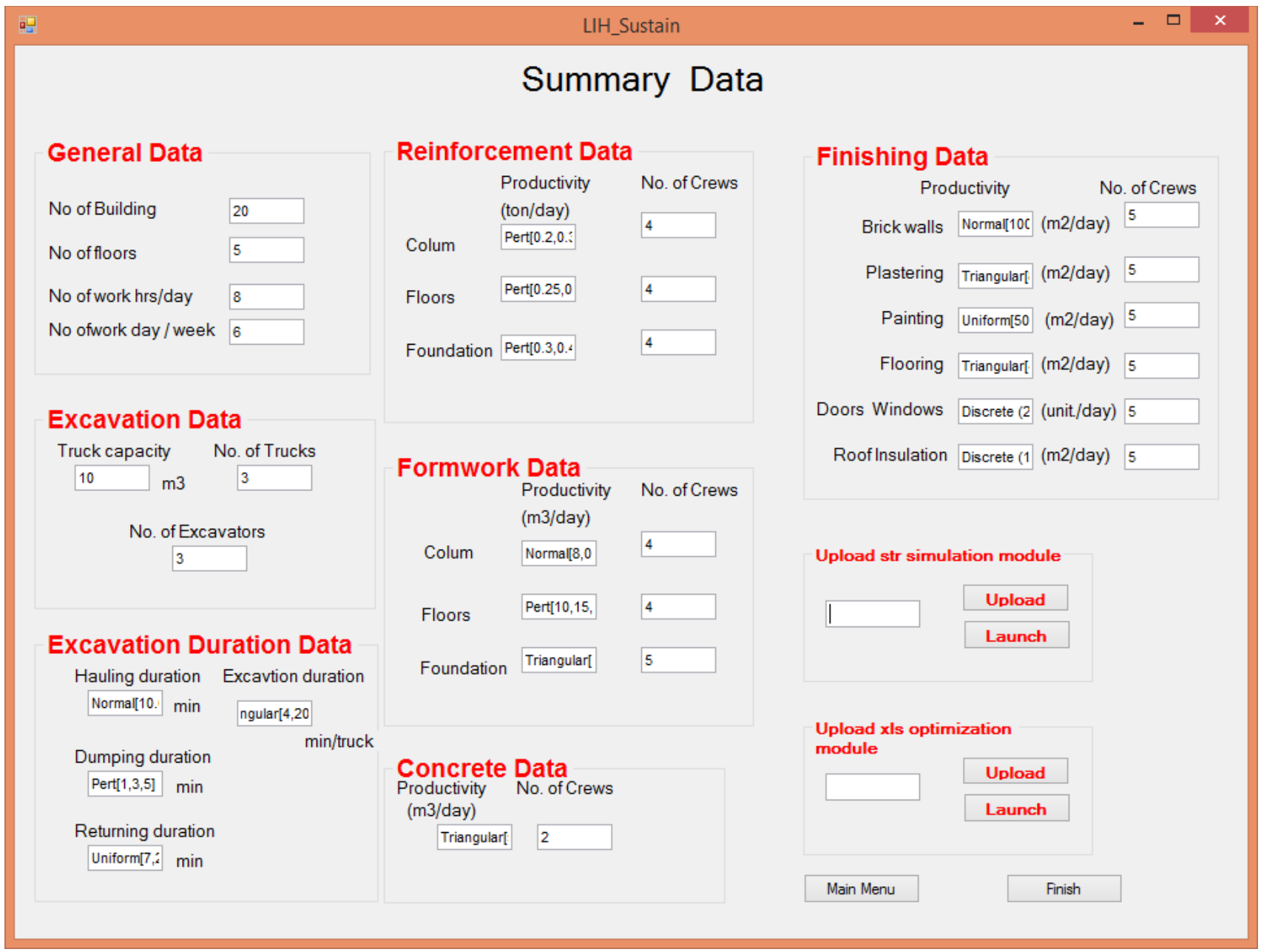

Figure 4. Data form for LIH activities. 
sed frame work on a LIH Project located in Badr City - Egypt. The project has 20 typical concrete building that consists of five floors with a floor area of $308 \mathrm{~m}^{2}$.

\subsection{Case Modeling}

Based on 2D CAD drawings, BIM model is developed using Autodesk Revit software. The different material quantities such as concrete, plastering, painting, bricks, flooring materials are determined based on the developed model. Sustainable material data are utilized within the Revit model such as Material Recycled content, Rapidly Renewable Material content, and Regional Materials content as per Figure 6. After developing the BIM Model, the model is exported to a database file. This file is used as an input file for the simulation model. Subsequently, the simulation input data are fed are listed in Tables 2 to 5 . Table 6 lists LCC for different material alternative.

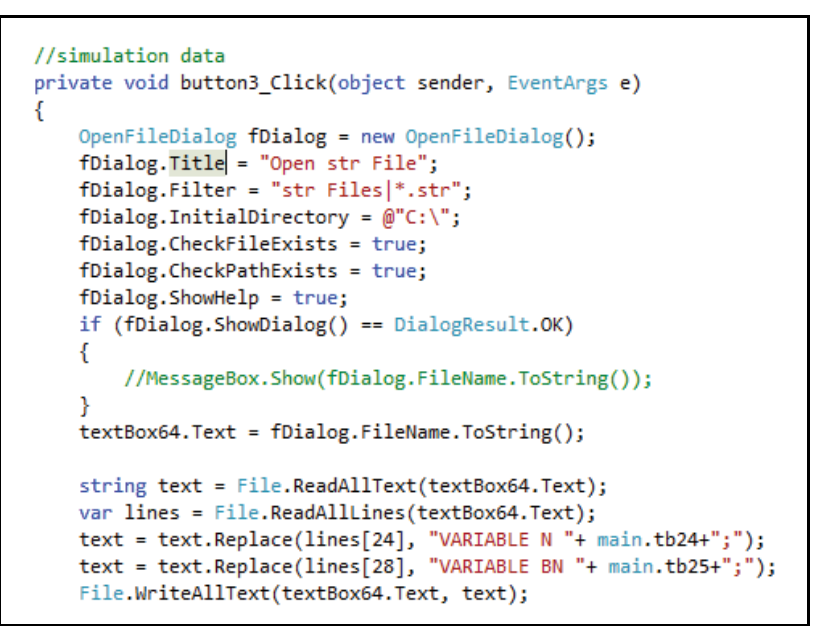

Figure 5. C\# code to access simulation model.

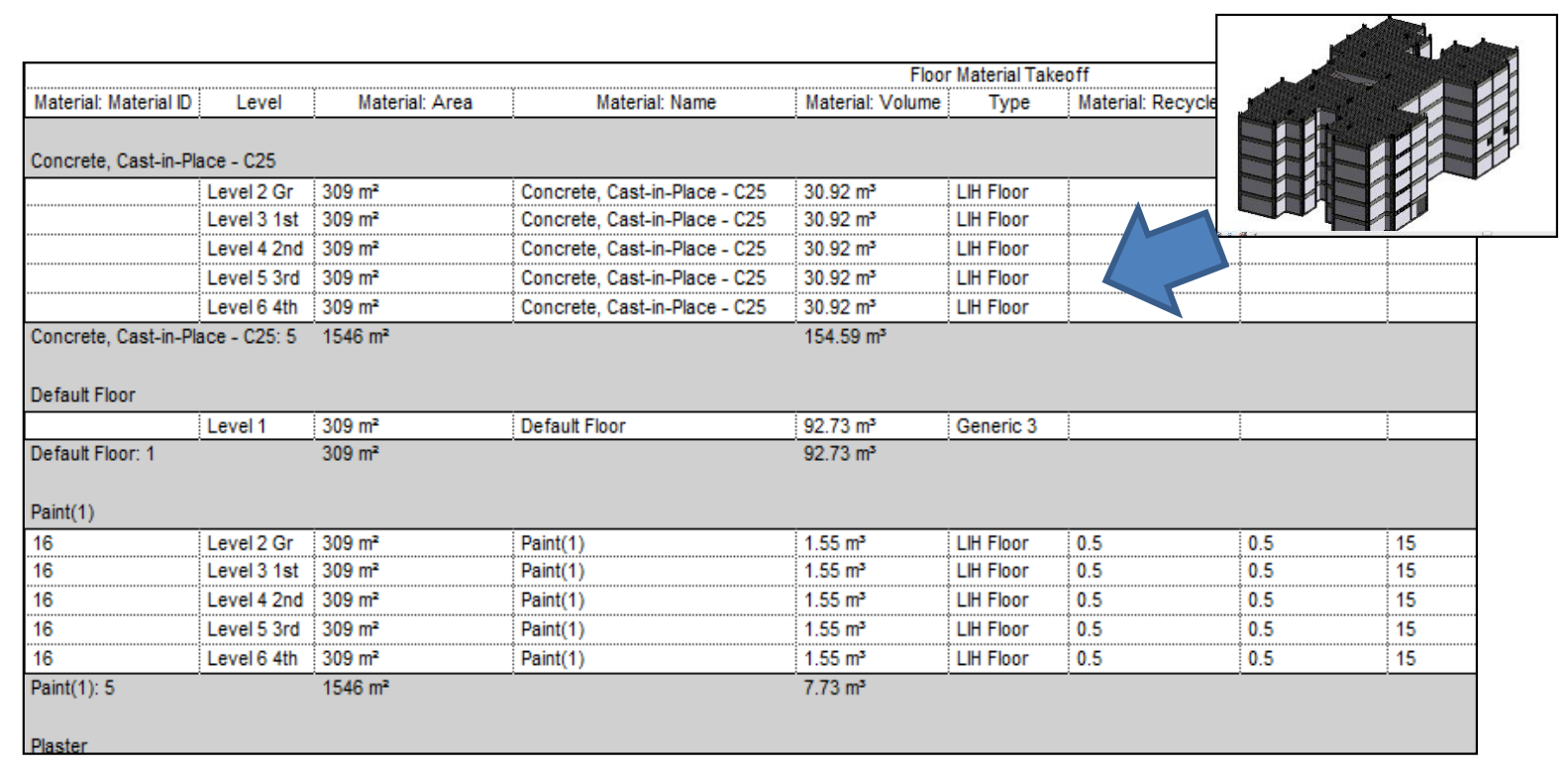

Figure 6. Material data and quantities extracted from BIM Model.

Table 2. Project General Input Data

\begin{tabular}{|c|c|c|c|c|c|c|}
\hline \multirow{2}{*}{$\begin{array}{l}\text { No. of } \\
\text { building units }\end{array}$} & \multirow{2}{*}{$\begin{array}{l}\text { No. of } \\
\text { floors }\end{array}$} & \multirow{2}{*}{$\begin{array}{l}\text { No. of working } \\
\text { hours per day }\end{array}$} & \multirow{2}{*}{$\begin{array}{l}\text { No. of working } \\
\text { days per week }\end{array}$} & \multicolumn{3}{|c|}{ Excavation Data } \\
\hline & & & & Truck capacity & No. of Trucks & No. of Excavators \\
\hline 20 & 5 & 8 & 6 & $10 \mathrm{~m}^{3}$ & 3 & 3 \\
\hline
\end{tabular}

Table 3. Excavation Duration Input Data

\begin{tabular}{ll}
\hline Activity Description & Duration (min.) \\
\hline Excavation & Triangular $[4,20,25]$ \\
Hauling & Normal $[10,0.2]$ \\
Dumping & Pert $[1,3,5]$ \\
Returning & Uniform $[7,20]$ \\
\hline
\end{tabular}


Table 4. Foundation \& Skeleton Input Data

\begin{tabular}{llll}
\hline Activity Description & Productivity & Productivity (unit) & No. of Crews \\
\hline Concrete & Triangular [50,150, 250] & $\mathrm{m}^{3} /$ day & 2 \\
Col Reinforcement & Pert [0.2, 0.3, 0.4] & Ton/day & 4 \\
Floor Reinforcement & Pert [0.25, 0.35, 0.45] & Ton/day & 4 \\
Foundation Reinforcement & Pert [0.3, 0.4, 0.5] & Ton/day & 4 \\
Col Formwork & Normal $[8,0.4]$ & $\mathrm{m}^{3} /$ day & 4 \\
Floor Formwork & Pert $[10,15,20]$ & $\mathrm{m}^{3} /$ day & 4 \\
Foundation Formwork & Triangular $[12,14,20]$ & $\mathrm{m}^{3} / \mathrm{day}$ & 5 \\
\hline
\end{tabular}

Table 5. Finishing Input Data

\begin{tabular}{llll}
\hline Activity Description & Productivity & Productivity (unit) & No. of Crews \\
\hline Brick Walls & Normal [100, 0.8] & $\mathrm{m}^{2} / \mathrm{day}$ & 5 \\
Plastering & Triangular [80, 120, 150] & $\mathrm{m}^{2} / \mathrm{day}$ & 5 \\
Painting & Uniform [50,120] & $\mathrm{m}^{2} / \mathrm{day}$ & 5 \\
Flooring & Triangular [40,60,80] & $\mathrm{m}^{2} / \mathrm{day}$ & 5 \\
Doors \& Windows & Discrete $(20)$ & Unit/day & 5 \\
Roof Insulation & Discrete (150) & $\mathrm{m}^{2} / \mathrm{day}$ & 5 \\
\hline
\end{tabular}

Table 6. Material Alternatives Data

\begin{tabular}{|c|c|c|c|}
\hline \multirow{2}{*}{ Task Name } & \multicolumn{2}{|r|}{ Sustainable Material } & \multirow{2}{*}{ LCC Cost LE/unit } \\
\hline & ID & Name & \\
\hline \multirow[t]{5}{*}{ PC Foundation Casting } & Pc1 & 21 mpa Concrete with Portland Cement & 500 \\
\hline & Pc2 & 15\% Fly Ash Cement $21 \mathrm{mpa}$ & 550 \\
\hline & $\operatorname{Pc} 3$ & $30 \%$ Fly ash Cement $21 \mathrm{mpa}$ & 570 \\
\hline & $\operatorname{Pc} 4$ & Generic Concrete Products with Slag 21mpa & 650 \\
\hline & Pc5 & Precast Conc $21 \mathrm{mpa}$ & 900 \\
\hline \multirow[t]{5}{*}{ RC Foundation Casting } & $\mathrm{RcF} 1$ & 28 mpa Concrete with Portland Cement & 1099.9 \\
\hline & $\mathrm{RcF} 2$ & 15\% Fly Ash Cement $28 \mathrm{mpa}$ & 1119.9 \\
\hline & $\mathrm{RcF} 3$ & $30 \%$ Fy Ash Cement $28 \mathrm{mpa}$ & 1139.9 \\
\hline & $\mathrm{RcF} 4$ & Generic Concrete Products with fly Ash $28 \mathrm{mpa}$ & 1159.9 \\
\hline & RcF5 & Precast Conc $28 \mathrm{mpa}$ & 1499.9 \\
\hline \multirow[t]{5}{*}{ Water Insulation } & WrIn1 & Cold Applied Bitumen & 18 \\
\hline & WrIn2 & High-density Polyethylene (HDPE) (5\% reuse) & 55 \\
\hline & WrIn3 & Ansomat (5\% reuse) & 50 \\
\hline & WrIn4 & Water Proofing Liquid & 40 \\
\hline & WrIn5 & Insultion Type 5 & 88 \\
\hline \multirow[t]{5}{*}{ Columns Casting } & CoCs1 & 28 mpa Concrete with Portland Cement & 1500 \\
\hline & $\mathrm{CoCs} 2$ & $15 \%$ Fly Ash Cement $28 \mathrm{mpa}$ & 1550 \\
\hline & $\mathrm{CoCs} 3$ & $30 \%$ Fly Ash Cement $28 \mathrm{mpa}$ & 1650 \\
\hline & CoCs 4 & Concrete with fly Ash $28 \mathrm{mpa}$ & 1700 \\
\hline & CoCs5 & Precast Conc $28 \mathrm{mpa}$ & 1950 \\
\hline \multirow[t]{5}{*}{ Slab Casting } & S1Cs1 & 21 mpa Concrete with Portland Cement & 1500 \\
\hline & $\mathrm{S} 1 \mathrm{Cs} 2$ & 15\% Fly Ash Cement $21 \mathrm{mpa}$ & 1550 \\
\hline & $\mathrm{S} 1 \mathrm{Cs} 3$ & $30 \%$ Fy Ash Cement $21 \mathrm{mpa}$ & 1650 \\
\hline & SlCs4 & Concrete with Fly Ash $21 \mathrm{mpa}$ & 1700 \\
\hline & S1Cs5 & Precast Conc $21 \mathrm{mpa}$ & 1950 \\
\hline \multirow[t]{5}{*}{ Block Works } & Bk1 & Generic Brick ( Clay Bricks) & 420.3 \\
\hline & $\mathrm{Bk} 2$ & Concrete Masonry Units (CMU) & 467.4 \\
\hline & $\mathrm{Bk} 3$ & Lightweight Aerated Concrete Block & 1205.6 \\
\hline & $\mathrm{Bk} 4$ & Lightweight Precast Aerated Concrete Wall Panel & 1403.2 \\
\hline & Bk5 & Rice-straw Based Brick & 430 \\
\hline
\end{tabular}




\begin{tabular}{llll}
\hline Plastering & Ps1 & Cement Mortar & 55 \\
& Ps2 & American Clay Earth Plaster & 107 \\
Flooring & F11 & Ceramic Tile With Recycled Glass 75\% RC & 54.1 \\
& F12 & Linoleum Flooring & 198.9 \\
& Fl3 & Terrazzo & 83.9 \\
& F14 & Wood Plank Flooring & 858.6 \\
& F15 & Natural Cork Flooring with 93\% RC renewable & 767.3 \\
Painting & Pn1 & Jotun Paints & 95.5 \\
& Pn2 & Hashmi Stone & 181.6 \\
& Pn3 & Waterborne (or Latex) Paints & 109.4 \\
& Pn4 & Stucco & 189.3 \\
& Pn5 & Terraco Paints & 87.8 \\
Insulation & In1 & Solid Foam (5 cm) & 65 \\
& In2 & Rockwool & 150.1 \\
& In3 & Blown Cellulose & 130.1 \\
& In4 & Rice Hulls & 30.1 \\
& In5 & Vegatable-based Foam & 145 \\
& D\&W1 & Wood Doors and Windows 1 & 1838.2 \\
& D\&W2 & Wood Doors and Windows 2 & 815.6 \\
& D\&W3 & Wood Doors and Windows 3 & 870.4 \\
& D\&W4 & Aluminum Doors and Windows p.s Type & 1006.9 \\
& D\&W5 & Aluminum Doors and Windows Tango Type & 1281.9 \\
\hline
\end{tabular}

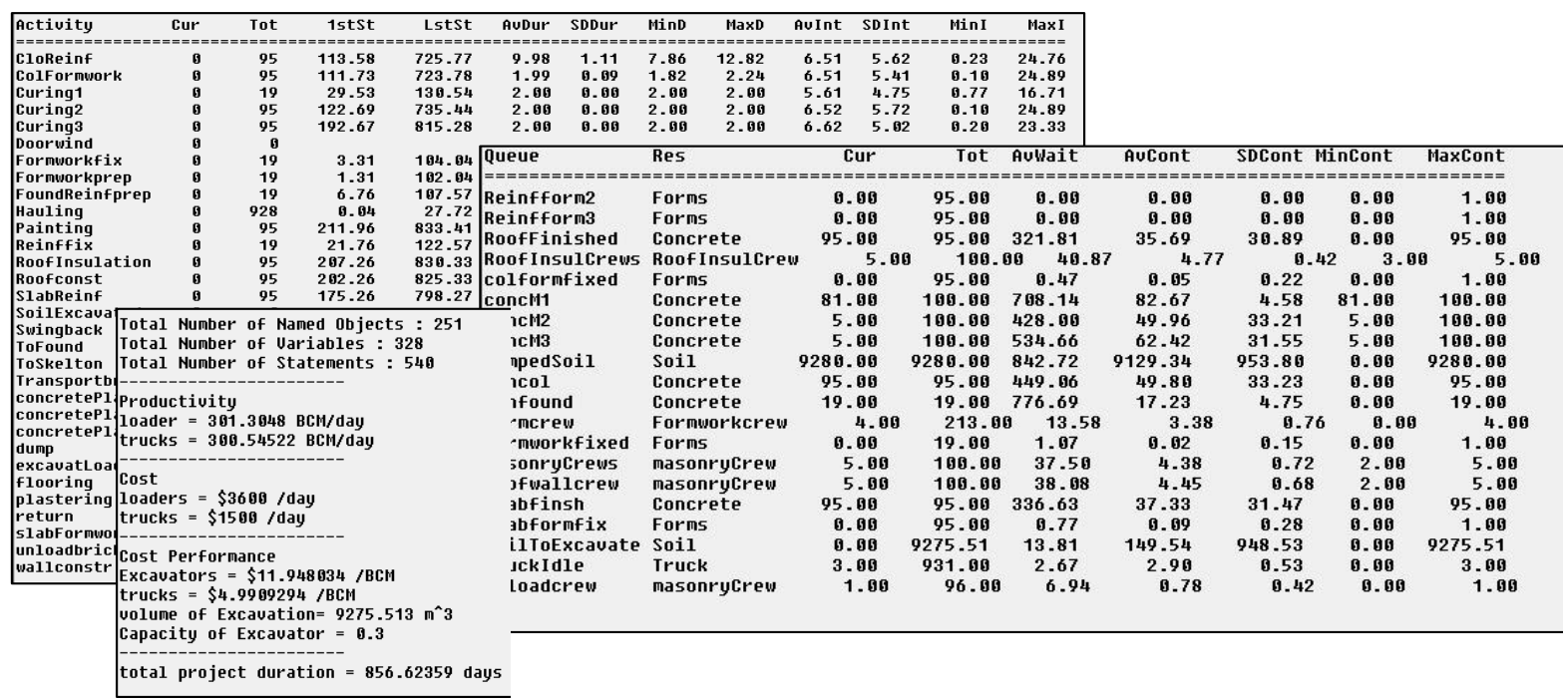

Figure 7. Simulation output statistics.

\subsection{Case Output}

Simulation report is generated by Stroboscope. It has detailed statistics for all resources and activities. Resources detailed and activities statistics (Average, minimum and maximum duration) are calculated as shown in Figure 7. LEED Materials calculator uses the defined material data to calculate the LEED points achieved. The cost is determined using the quantities extracted from Revit and the defined alternatives. The optimal solutions are obtained by using the genetic algorithms add-in. System dynamics is used as a decision-making tool for constructing sustainable LIH projects by conducting a detailed analysis of the costs and LEED credits through the various years of building life cycle. For genetic algorithm operators in the optimization model: population size, number of generations, crossover rate, and mutation rates are set to 50, $100,0.5$, and 0.2 , respectively. The best solution that can be chosen by decision-makers in the Egyptian government of building-materials alternatives to achieve the sustainable LIH with reasonable life cycle cost by fewer premiums for LEED advantages is based on the optimization model's scenarios that shown in Figure 8. Because low-income groups are not always willing to pay a premium for gaining green buildings, 


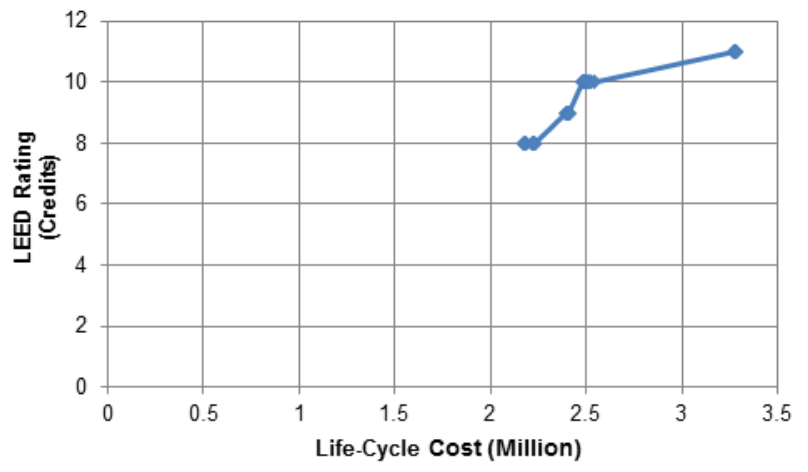

Figure 8. LEED credit vs. Life-Cycle cost.

the decision-makers try to prepare a sustainable design as much as possible (Langdon, 2009). For that, scenario of PcFn1, RcFn1, WrIn1, CoCs1, Sl\&BCs1, Bk1, Ps1, Fl1, Pn5, ThIn4, and D\&W2 that has a total LCC of 2,188,530 LE and associated 8 LEED credits has been selected for simulating and monitoring the effect of the building materials that have been selected on environmental and economic behaviors of LIH building through different years in its life cycle. Figure 8 shows how the total LCC cost and LEED points are changed throughout the generations.

\subsection{Decision Analysis}

Based on the qualitative analysis for the behavior of the SD model through a CLD, model formulation in form of equations and codes is considered to facilitate conducting a computer simulation and the quantitative analysis of proposed model. The simulation is performed over a total period of 50 years. After feeding a SD model by initial values and necessary functions of its variables, quantitative results are derived by simulation. Figure 9 shows simulation results of LCC of the building through its operational lifetime. A closer looking at the simulation results can be concluded that the total cost of ownership will increase gradually from LE. 1,834,536 (\$262, 076) during the construction phase to LE. $2,188,530$ ( $\$ 312$, 647 ) by the end of simulation run. As a result, costs required from operation phase to demolition phase would be approximately LE. 353,993 (\$50,570). Comparing the operational cost of this scenario with any other scenario contains traditional

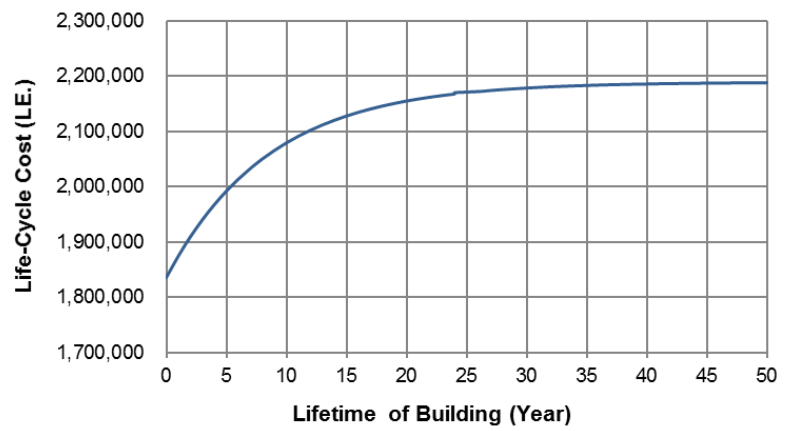

Figure 9. Life cycle cost analysis of sustainable building. building materials can be concluded that the operational costs of sustainable materials are much less than those from the traditional materials. Based on the sustainable properties of materials of this scenario, the building will achieve eight-credit points of LEED out of the 11 points available, but fails to satisfy those from credits 4 and 6 related to recycled content and rapidly renewable materials.

\section{Conclusions}

This research presented a framework that integrates Building Information Modeling (BIM) with computer simulation, optimization and system dynamics in Low Income Housing (LIH) projects. The proposed framework consists of four main components; BIM model, Project computer Simulation Model, LEED optimization model, and system dynamics model. The BIM model is used to represent the geometrical information and the different properties of Low Income Housing building such as building elements properties, material properties and its quantities, design alternatives and project location. Whereas, simulation model is developed using Stroboscope language to estimate the total duration of buildings construction in a LIH project, taking in the consideration the number of utilized resources for a given number of the buildings in a specific project. Optimization model considers Leadership in Energy and Environmental Design (LEED) rating system to evaluate the sustainability of buildings. The problematic behavior of the system was visualized by the Casual-Loop Diagram (CLD) using VENSIM software. STELLA software package was used to formulate the analytical model of SD to be capable of simulating and conducting the necessary analysis for the decision of experts.

A case study was presented for Social Housing project in Badr City - Egypt study to demonstrate the use of the practical use of the proposed framework. The optimal solutions are obtained by triggering optimization model. Different genetic algorithm operators were altered including; population size, number of generations, crossover rate, and mutation. Subsequently, system dynamics model was used as a decisionmaking tool for constructing sustainable LIH projects by conducting a detailed analysis of the costs and LEED credits through the 50 years of building life cycle. For the considered analyzed scenario, the result revealed that the operational costs of sustainable materials are much less than those from the traditional materials.

Acknowlegements. This research was financially supported by STDF (the Science \& Technology Development Fund), Egypt, Grant No. 63.

\section{References}

Azhar, S., Carlton, W. A., Olsen, D., and Ahmad, I. (2011). Building information modeling for sustainable design and LEED ${ }^{\circledR}$ rating analysis. Autom. Constr., 20(2), 217-224. http://dx.doi.org/10.10 16/j.autcon.2010.09.019

Beatty, T.L. (2002). Life-cycle cost analysis primer, U.S. Department 
of Transportation, Federal Highway Administration, Office of Asset Management. http://isddc.dot.gov/OLPFiles/FHWA/010621. pdf.

Bilec, M.M. (2007). A hybrid life cycle assessment model for construction processes, $\mathrm{PhD}$. Thesis, School of Engineering, University of Pittsburgh, USA.

Chen, H.M. and Huang, P.H. (2013). 3D AR-based modeling for discrete-event simulation of transport operations in construction. Autom. Constr., 33, 123-136. http://dx.doi.org/10.1016/j.autcon. 2012.09.015

Cheung, F.K.T., Rihan, J., Tah, J., Duce, D., and Kurul, E. (2012) Early stage multi-level cost estimation for schematic BIM models. Autom. Constr., 27, 67-77. http://dx.doi.org/10.1016/j.autcon.2012. 05.008

Deb, K., Pratap, A., Agarwal, S., and Meyarivan, T. (2002). A fast and elitist multiobjective genetic algorithm: NSGA-II. IEEE Trans. Evol. Comput., 6(2), 182-197. http://dx.doi.org/10.1109/4235.996 017

Florez, L. and Castro-Lacouture, D. (2013). Optimization model for sustainable materials selection using objective and subjective factors. Mater. Des., 46, 310-321. http://dx.doi.org/10.1016/j.matdes. 2012.10.013

Frenning, L., Hovstadius, G., Alfredsson, K,. Beekman, B., Angle, T., Bower, J., Hennecki, F.W., McKane, A., Doolin, J., and Romanyshyn, G. (2001). Pump life cycle costs: a guide to LCC analysis for pumping systems, Hydraulic Institute and Europump, Parsippany, New Jersey, USA, Brussels, Belgium.

Fuller, S. (2010). Life-cycle cost analysis (LCCA), National Institute of Standards and Technology (NIST). http://www.wbdg.org/resour ces/lcca.php.

Han, S., Love, P., and Peña-Mora, F. (2013). A system dynamics model for assessing the impacts of design errors in construction projects. Math. Comput. Model., 57(9), 2044-2053. http://dx.doi.org/ 10.1016/j.mcm.2011.06.039

John, G., Clements-Croome, D., and Jeronimidis, G. (2005). Sustainable building solutions: a review of lessons from the natural world Build. Environ., 40(3), 319-328. http://dx.doi.org/10.1016/j.build env.2004.05.011

Jones Lang LaSalle (JLL). (2011). Why affordable housing matters? http://www.joneslanglasalle-mena.com/ResearchLevel1/JLLMEN A_Affordable\%20Housing_2011.pdf.

Kibert, C.J., Olbina, S., Oppenheim, P., Ries, R., and Walters, R. (2010). Life cycle cost guidelines for materials and building systems for Florida's public educational facilities, University of Florida.

Langdon, D. (2009). Cost of green analysis for affordable housing in Seattle and Portland. http://www.seattle.gov/Documents/Depart ments /OSE/Cost-of-Green-AffordHousing.pdf.

Love, P.E.D., Holt, G.D., Shen, L.Y., Li, H., and Irani, Z. (2002). Using systems dynamics to better understand change and rework in construction project management systems. Int. J. Proj. Manage., 20(6), 425-436. http://dx.doi.org/10.1016/S0263-7863(01)00039-4

Mallick, R.B., Radzicki, M.J., Zaumanis, M., and Frank, R. (2014). Use of system dynamics for proper conservation and recycling of aggregates for sustainable road construction. Resour. Conserv. Recycling, 86, 61-73. http://dx.doi.org/10.1016/j.resconrec.2014. 02.006

Mansour, A., Srebric, J., and Burley, B.J. (2007). Development of straw-cement composite sustainable building material for low-cost housing in Egypt. J. Appl. Sci. Res., 3(11), 1571-1580.

Marco, A.D. and Rafele, C. (2006). Using system dynamics to understand project performance, In: Book of Abstracts and Congress Programme, Slovenian Project Management Association (SVN), 1st ICEC\&IPMA Global Congress on Project Management, Ljub ljana 23-26 April 2006, ISBN: 961-6597-00-0.

Martinez, J.C. (2006). STROBOSCOPE-state and resource based simulation of construction process, $\mathrm{PhD}$ Thesis, University of Michigan, US.

Marzouk, M. and Moselhi, O. (2004). Multiobjective optimization of earthmoving operations. J. Constr. Eng. Manage., 130(1), 105-113. http://dx.doi.org/10.1061/(ASCE)0733-9364 (2004)130:1(105)

Marzouk, M., Abdelhamid, M., and Elsheikh, M. (2013) Selecting sustainable building materials using system dynamics and ant colony optimization. J. Environ. Eng. Landsc. Manage., 21 (4), 237247. http://dx.doi.org/10.3846/16486897.2013.788506

Marzouk, M. and Azab, S. (2014). Environmental and economic impact assessment of construction and demolition waste disposal using system dynamics. Resour. Conserv. Recycling, 82, 41-49. http://dx.doi.org /10.1016/j.resconrec.2013.10.015

Marzouk, M., Omar, O., Abdel Hamid, M., and El-Said, M. (2010). An optimization algorithm for simulation-based planning of lowincome housing projects. J. Adv. Res., 1(4), 291-300. http://dx.doi. org/10.1016/j.jare.2010.06.002

Marzouk, M., Said, H., and El-Said, M. (2008) Special-purpose simulation model for balanced cantilever bridges. ASCE. J. Bridge Eng., 13(2), 122-131. http://dx.doi.org/10.1061/(ASCE)10840702(2008) 13:2(122)

Onat, N.C., Egilmez, G., and Tatari, O. (2014). Towards greening the US residential building stock: a system dynamics approach. Build. Environ., 78, 68-80. http://dx.doi.org/10.1016/j.buildenv.2014.03.0 30

Park, M., Ji, S., Lee, H., and Kim, W. (2009). Strategies for designbuild in Korea using system dynamics modeling. ASCE. J. Constr. Eng. Manage., 135(11), 1125-1137. http://dx.doi.org/10.1061/(AS CE)CO.1943-7862.0000095

Pulselli, R.M., Simoncini, E., Pulselli, F.M., and Bastianoni, S. (2007). Emergy analysis of building manufacturing, maintenance and use: Em-building indices to evaluate housing sustainability. Energy Build., 39(5), 620-628. http://dx.doi.org/10.106/j.enbuild. 12006.10.004

Radzicki, M.J. and Taylor, R.A. (2008). Origin of system dynamics: Jay W. Forrester and the history of system dynamics, In: U.S. Department of Energy's Introduction to System Dynamics.

Saunders, J.H. (1998). The technology of system dynamics. http:// www.johnsaunders .com/papers/sysdyn.htm.

Shin, M., Lee, H.S., Park, M., Moon, M., and Han, S. (2014). A system dynamics approach for modeling construction workers' safety attitudes and behaviors. Accid. Anal. Prev., 68, 95-105. http://dx. doi.org/10.1016/j.aap.2013.09.019

Song, L. and Eldin, N.N. (2012). Adaptive real-time tracking and simulation of heavy construction operations for look-ahead scheduling. Autom. Constr., 27, 32-39. http://dx.doi.org/10.1016/j.autcon. 2012.05.007

Stanford University. (2005). Guidelines for life cycle cost analysis. http://lbre.stanford.edu/sites/all/lbre-shared/files/docs_public/LCC A121405.pdf.

Tang, V. and Vijay, S. (2001). System dynamics origins, development, and future prospects of a method, Research Seminar in Engineering Systems, ESD. 83.

U.S. Green Building Council (USGBC). (2009). Leadership in energy and environmental design: green building rating system (LE $E D)$, US Green Building Council, 3.

U.S. Green Building Council (USGBC). (2012). About USGBC, U.S. Green Building Council. http://www.usgbc.org/DisplayPage.aspx? CMSPageID $=124$.

Wolstenholme, E. (1985). A methodology for qualitative system dynamics, In: Proceedings of the 1985 System Dynamics Conferen$c e$, Nathan Forrester, Keystone, CO, 1049-1058. 
Yuan, H. and Wang, J. (2014). A system dynamics model for determining the waste disposal charging fee in construction. Eur. J Oper. Res., 237(3), 988-996. http://dx.doi.org/10.1016/j.ejor.2014.02.034

Yuan, H.P., Shen, L.Y., Hao, J.L., and Lu, W.S. (2011). A model for cost-benefit analysis of construction and demolition waste mana- gement throughout the waste chain. Res. Conser. Recycling, 55(6), 604-612. http://dx.doi.org/10.1016/j.resconrec.20 10.06.004

Zhang, H. (2008). Multi-objective simulation-optimization for earthmoving operations. Autom. Constr., 18(1), 79-86. http://dx.doi.org /10.1016/j.autcon.2008.05.002 